\title{
The Zootic Disclimax Concept
}

\section{ALAN A. BEETLE}

Highlight: Some ecologists are using the term "zootic climax" in the same sense that range managers use the term "zootic disclimax." If our national parks are to be managed in order that they be natural, it will be important for administrators to understand these two terms and how they differ from the Climatic Climax.

No matter how vigorously protested or ignored, it can hardly be considered a secret that throughout this century many reports of poor range conditions in Wyoming have involved the ungulate populations in two national parks, Yellowstone and Grand Teton (Preble, 1911; Roosevelt 1912; Graves and Nelson, 1919; Sheldon, 1927; Beetle, 1952, 1961, 1962, and 1968).

Citing only one or two of these-in 1947, Victor H. Cahalane of the Biology Division of the National Park Service reported in the Journal of Mammalogy that "winter range within Yellowstone Park has been severely damaged by decades of over-use" and that "overpopulations of mammals threatened destruction of vital foragc."

On adjoining Forest Service lands, A. $K$. Wogensen of the Forest Service in 1951 estimated 27,000 acres in the Gros Ventre, 12,000 acres near Jackson, and 8,000 acres in the Hobach were "range in poor or depleted condition on which accelerated soil loss is evident. Normally should be taken out of use." That is if the use involved cattle permits, then the use could be cancelled; but because the use is

The author is professor, Department of Range Management, University of Wyoming, Laramie.

The article is published with the approval of the Director, Wyoming Agricultural Experiment Station, as Journal Article $\mathbf{5 7 1}$.

Manuscript received February 8, 1973 wild game, numbers actually increased.

Lest you think that the reports of damage are confined to the winter range, see what A. R. Croft of the Forest Service administration and Lincoln Ellison of the Intermountain Forest and Range Experiment Station in 1960 said about " Damage-and in some cases destruction-of the soil and vegetation on the high mountain range-watersheds which supply more of the elk's spring, summer, and fall feed.

"Damage to these vital resources that has resulted in low productivity of forage-and in some cases no productivity at all-cannot long continue without serious consequences. The problem is real and vital. It has many aspects that reach far beyond the welfare of the animals themselves because erosion of watershed soil also affects water quality, streamflow characteristics, fish habitat, aesthetic values, and the economy of local communities. The problem calls for statesmanlike action by all those interested in the welfare of the elk and the range and watersheds on which they depend. A program of management that will assure perpetuity of the elk and the related soil and forage resources is urgently needed."

There are many exclosures on western range lands. Traditionally when a contrast has appeared, the plants inside have been labelled decreasers and increasers and their rclative composition has been accepted as an indication of range quality.
Increasers associated with invaders inside have been signals of range deterioration. Exclosures have been used to create a climatic climax. On livestock ranges that have departed from climatic climax, animal numbers have been reduced as a matter of coursc. The assumption has been implicit that overgrazed ranges offered less nutrition and less ground cover. Lower nutritive content of forage has been assumed to be a contributive cause of lower calf crops, and ground cover has been related to erosion and water quality. As will be shown, to advocates of the zootic disclimax these things may be quite natural, if not unavoidable.

In 1971, several papers were published by the naturalists in Grand Teton and Yellowstone National Parks evaluating range practices for those areas. As a footnote to the history of range and wildlife management, it should be recorded that in the latter half of the twentieth century there is a school of ecologists whose ideas center around their term "zootic climax."

These concepts have some rather unusual aspects which deserve to be discussed fully, since many of them are contradictory to current textbook teachings in curricula of range or wildlife management in which climatic climax is considered to be natural. As Houston (1971a) says, "A national park ecosystem requires a unique approach to research and management." Again in 1972, Houston says, "Criteria used in forestry and range and wildlife management, where vegetation and wildlife are harvested as a crop, do not necessarily apply to national 
parks." At times, Forest Service personnel, the Sierra Club, and wildlifers do not think of wilderness (or game) areas as different from a park.

This school has developed as a direct result of percussive numbers of grazing ungulates in and around two national parks, Yellowstone and Grand Teton.

The term "zootic climax" is ascribed to Daubenmire (1968) and is defined as a "stabilized biotic disclimax." The assumption of the new school is that in national parks, in national forests, and on big game ranges such disclimax stability is more natural than a climatic climax. It is created and maintained by native ungulates regardless of whether they are occupying their traditional range (as the elk are), or are occupying greatly enlarged ranges (as the moose are); and whether or not the balance has already been upset by the elimination of a native ungulate such as the bison.

Since, by definition, climate dictates climax and since, also by definition, a "zootic climax" is dictated by a biotic influence which is asymptotic (i.e. if the grazing ungulate is removed, the trend created away from climatic climax is reversible) the term has to be "zootic disclimax."

Because exclosures tend to recreate climatic climaxes which contrast sharply with zootic disclimax, exclosures are being removed from Grand Teton and Yellowstone National Parks. According to Cole (1971), "Interpretations that such exclosures illustrate how things should be in a park would more often than not be confusing artificial with natural conditions." Quoting again from Cole (1971), interpretations based on exclosures "require an awareness that protected vegetation represents an artificial "standard' which increases in artificiality over time." Exclosures are only good as a "measure of succession rate or site potential without the biotic effects of large herbivores."

On August 16, 1972, Gary E. Everhardt, superintendent of Grand Teton National Park, wrote to Senator Clifford Hansen as follows (see Archives, Society for Range Management, University of Wyoming library):

Prior to the summer of 1972 , four range exclosures were present in Grand Teton National Park. Two of these were removed by the Youth Conservation Corps this summer. The two remaining exclosures are scheduled for removal in the future as funds and manpower become available.

These exclosures are rectangular plots of 5 to 15 acres surrounded by a fence substantial cnough to exclude large grazing animals. They were established during the 1950's to determine the influence of grazing animals on vegetation. They demonstrate that a somewhat different vegetation pattern results when the influence of large mammals is removed. When the exclosures were established, less information was available on past levels of game use in the Jackson Hole area than is now available. More recent studies have established beyond question that large populations of elk have been present in the Jackson Hole area for many years-certainly since the arrival of white man.

Primary management goal of the National Park Service is to maintain ecosystems in as natural a state as possible. Large game populations are part of these natural ecosystems. Conditions within exclosures clearly reprcsent a departure from natural conditions.

Misinterpretations of the situation within exclosures are often made. It is commonly assumed incorrectly that the condition inside the exclosure is the natural condition. The National Park Service has received no information which indicates a valid need for the continued maintenance of the four exclosures within Grand Teton National Park. Since they constitute a departure from natural conditions, are a significant aesthetic intrusion and are sources of public confusion and misinformation, it is not deemed wise to continue spending public funds for their maintenance. When a voluntary work force was made available for removal of two of the exclosures, advantage was taken of this circumstance.

Mr. Everhardt, a relatively new administrator in Grand Teton National Park, has not been informed about the history, use, maintenance, study or need for range exclosures.

With range exclosures eliminated as evidence of what is pristine, the void is filled by the use of old photos. When one uses old photos, one soon finds that what one has been led to believe is "aesthetic" is not really compatible with "scientific values." Such unaesthetic habitat features as bare ridges, browse line, and fire scars become quite acceptable.

However, according to Loop (1972), "No attempt is made to "turn back the clock' so that the landscape appears exactly as it did in 1809 , when John Colter arrived. The important consideration is that natural ecological forces must be allowed to operate, subjecting animal and plant communities to the same proc- esses of selection which have influenced them for thousands of years."

Overwinter mortality acts as a natural check on population, and even if this mortality is high, it is still natural. Predators are useful to justify "the maintenance of representative populations of native ungulates" but are not essential to their population control. If the forage deteriorates and leads to poor nutrition in the ungulates, and if this in turn leads to low rates of ungulate increase because of infant mortality, either prenatally or post-natally, this is also natural.

The dominant grazing ungulate is the apex of the food chain and the only element in the habitat worthy of consideration if one wishes to "preserve representative natural environments and native biota as integrated wholes (i.e. ecosystems)." This means that if associated animals (even associated grazing ungulates like the deer) are forced into marginal situations and decrease in numbers, this is natural. If the plant populations become disclimax permanently, this is natural.

Dominant grazing ungulates will not reduce the food sources that limit their own densities according to Houston (1971a), who states: "Ungulates participate in plant successional processes and may be capable of reducing or eliminating remnant vegetation types that are no longer a number-limiting food source." On this basis, there should be concern for aspen as a community in this area. Those concerned with the survival of rare and endangered species will find little comfort in this "rationale" which can account for the elimination of a whole community.

The only force equally natural with ungulate grazing is fire. This has been proven by photographs. According to Loop (1972), "In view of the undisputable past role of fire as a key process shaping patterns of vegetation, continued attempts at total fire suppression in National Parks will clearly result in a loss of any semblance of natural ecosystems."

According to Cole (1971), "Primary succession is slower without the biotic effects of large herbivores," but "fire" may cause "unnatural secondary or retrogressive succession" just as do "artificially maintained densities of domestic or wild herbivores"; but on the other hand, "even natural densities of wild herbivores maintain some vegetation within their habitats as stabilized seral stages, or what may be called zootic climaxes." At this point one is faced with the question as to whether "wild" fires can undo the ecological changes caused by ungulate grazing. 
There is a disputable theory that coniferous forests always replace aspen and fire is necessary to restore the aspen disclimax. Old photos show that woody vegetation, both brush (sagebrush) and forest (conifers) have increased with the years of protection from fire, while other brush (willows) and other forests (aspen) have decreased.

According to Houston (1971b), neither willow nor aspen are important feed sources for the northern Yellowstone herd and therefore are also ecologically unimportant.

Since this group advocating the acceptance of the zootic disclimax is ncw, traditionalists should be tolerant while some of the inconsistencies are worked out. It appears that (1) Cole (1971) has offered two ecologically different definitions of zootic climax: (a) "stabilized seral stage"; and (b) "stabilized biotic disclimax," and which is meant should be clarified; (2) with fire and ungulate grazing assuming roles as the only natural forces in ecosystems, it will be necessary to show how climates and the fragile soil mantles fit into the scheme of things; (3) aspen regenerate without fire in all exclosures in the Teton County area. The latter is not an important fact since quaking aspen is no longer an important food source. But if not an important food source and not an intrinsic climax type, why try to regenerate quaking aspen with fire? (4) granting that management decisions and objectives may differ in a national park, research in a national park is not "unique." Aren't the laws of natural science universal? (5) a more definite statement on how an "ecologically complete habitat" is identified needs to be developed, especially since the new school chooses to apply the principles equally to Yellowstone and to Grand Teton National Parks and it is not clear how the unlimited winter feeding of elk in the national elk refuge contributes to an "ecologically complete habitat."

As long ago as 1937, W. B. Grange of the Section of Food Habits, Division of Wildlife Research, Branch of Bioligical Survey, had a proper perspective in his "Feeding Wildlife in Winter." What he said then is as applicable to good range management as ever:

Under strictly natural conditions, game-mammal populations are usually well adjusted to the available browse and range; if not, the undesirable animal surplus is removed by various natural agencies, so that increase is held in sufficient check to prevent outrunning the food supply.

It is to be realized that two separate problems are present for solution in each instance of food failure:

(1) the problem of emergency feeding, by which the animals may be tided over winter; and

(2) the more difficult matter of so restoring the range that emergency feeding will no longer be necessary.

The advocates of the new school that gives greater reality to zootic disclimax than to climatic climax point to the surplus of animals as their success-the failure to feed them naturally belongs to range managers.

But let us return to 1937 and $\mathrm{Mr}$. Grange: "Most situations of this kind, fortunately, do not appear in a single winter but result from causes that have been operating for several years. Consequently, there are numerous danger signals that the game manager can read well in advance of the actual emergency. One of these is the establishment of a 'deer line' in woodland tracts, that is, the disappearance of the lower vegetation up to a level that the deer can reach by standing on their hind legs, a common method of obtaining browse feed. By the time the deer line has been formed, the range is already far deteriorated. It is important, therefore, to note the beginning of this overgrazed condition, and keen observers will be able to detect an incipient deer line. Another indication of range deterioration is the eating of certain relatively unpalatable species of browse in quantity."

Reports continue to be circulated indicating that there is no need for concern about elk management in Wyoming. As recently as last December (Jorgason, 1972), the Wyoming Wildlife magazine reported that "summer range for the northern Jackson Hole elk herd is ample for the herd's present needs. Vegetative checks have been made to determine the effects of elk foraging on these summer ranges and elk use on key plants has only been 50 percent or less."

Is the whole zootic disclimax concept a whitewash of elk management policies, or does it deserve a place in our

\section{Literature Cited}

Beetle, A. A. 1952. A 1951 survey of summer elk in the Teton wilderness area. Wyo. Range Manage. 51:1-5.

Beetle, A. A. 1961. Range survey in Teton County, Wyoming. Part I. Ecology of range resources. Wyo. Agr. Exp. Sta. Bull. 376. $42 \mathrm{p}$.

Beetle, A. A. 1962. Range survey in Teton County, Wyoming. Part II. Utilization and condition classes. Wyo. Agr. Exp. Sta. Bull. $400.38 \mathrm{p}$.

Beetle, A. A. 1968. Range Survey in Teton County, Wyoming. Part III. Trends in vegetation. Wyo. Agr. Exp. Sta. Res. J. 26:1-16.

Cahalane, V. H. 1947. Wildlife management in the National Park system. Yosemite Nature Notes, 26:66-70.

Cole, Glen F. 1971. An ecological rationale for the natural or artificial regulation of native ungulates in parks. Trans. of the 36 North Amer. Wildl. and Natur. Resources Conf. p. 417-425.

Cole, Glen F. 1971. Some considerations in the use of exclosures to assess the biotic effects of herbivores and departures from natural conditions in Yellowstone National Park. National Park Serv. Infor. Pap. No. 13. 5 p. processed.

Croft, A. R., and Lincoln Ellison. 1960. Watershed and range conditions on Big Game Ridge and vicinity, Teton National Forest, Wyoming. U. S. Dep. Agr., Forest Serv., Ogden, Utah. 1-37 p.

Daubenmire, R. F. 1968. Plant communities: A textbook of synecology New York: Harper and Row. 300 p.

Grange, Wallace B. 1937. Feeding wildlife in winter. U. S. Dep. Agr., Farmer's Bull. 1783. $20 \mathrm{p}$.

Graves, H. S., and E. W. Nelson. 1919. Our National Elk Herds. U. S. Dep. Agr. Circ. $51.34 \mathrm{p}$.

Houston, D. B. 1971. Ecosystems of National Parks. Science 172: 648-651.

Houston, D. B. 1971. The status of research of ungulates in northern Yellowstone National Park. 21 p. Mimeo (paper presented at the Amer. Assoc. for the Advancement of Sci. Symp. on Res. in National Parks, Dec. 28, 1971).

Jorgason, James, 1972. The Big Herd. Wyo. Wildl. 12:23-27.

Loop, L. 1972. Fire ecology experiment scheduled in Jackson Hole. Jackson Hole News, Thursday, June 22, 18 p.

Preble, E. A. 1911. Report on condition of elk in Jackson Hole, Wyoming, in 1911. U. S Dep. Agr. Bull. 40.23 p, 7 plates.

Roosevelt, T. 1912. Comments on Yellowstone elk. Outlook, March 21, p. 713.

Sheldon, C. 1927. The conservation of the elk of Jackson Hole. Nat'l. Conf. Outdoor Recr. 1-36 p.

Wogensen, A. K. 1951. Game winter range conditions in the Jackson Hole Area. U. S. Forest Serv., Mimeo. 11 p. 